\title{
Viability of Probiotics (Lactobacillus acidophilus and Bifidobacterium bifidum) in set type yogurt made from buffalo milk
}

Muhammad Bilal ${ }^{1}$, Saima Inayat ${ }^{1 *}$, Saqib Manzoor ${ }^{1}$, Muhammad Imran $^{2}$, Mushtaq Hussain Lashari ${ }^{3}$ and Aizaz Hassan ${ }^{1}$

1. Department of Dairy Technology, University of Veterinary and Animal Sciences, Lahore-Pakistan

2. Department of Biochemistry, University of Veterinary and Animal Sciences, Lahore-Pakistan

3. Department of Life Sciences, The Islamia University of Bahawalpur, Bahawalpur-Pakistan

*Corresponding author's email: saima.inayat@uvas.edu.pk

Citation

Muhammad Bilal, Saima Inayat, Saqib Manzoor, Muhammad Imran, Mushtaq Hussain Lashari and Aizaz Hassan. Viability of Probiotics (Lactobacillus acidophilus and Bifidobacterium bifidum) in set type yogurt made from buffalo milk. Pure and Applied Biology. Vol. 10, Issue 4, pp978-987. http://dx.doi.org/10.19045/bspab.2021.100102

\begin{tabular}{llll}
\hline \hline Received: 26/10/2020 & Revised: 18/12/2020 & Accepted: 26/12/2020 & Online First: 02/01/2021 \\
\hline
\end{tabular}

\section{Abstract}

Yogurt is a well-known popular food that contains probiotics, such as Lactobacillus acidophilus, this strain is commonly incorporated in yogurt in some countries. Probiotics of yogurt found to have anti-oxidative properties and boost the immune system. Unfortunately in Pakistan there is no trend of accumulation of probiotics in dairy foods. Present study has been designed to incorporate probiotics in yoghurt, to study the best storage temperature and adequate level of probiotics for best yogurt production. The effect of refrigerated storage temperature at 4, 5 and $6^{\circ} \mathrm{C}$ on the viability after addition of probiotics (Lactobacillus acidophilus \& Bifidobacterium bifidum) in set type yogurt was observed for $28^{\text {th }}$ day's to identify the best storage temperature for probiotics. The viability of the probiotic micro-organisms were analyzed at 07 days interval. Results showed that storage at $4{ }^{\circ} \mathrm{C}$ showed the highest viability of Lactobacillus acidophilus and Bifidobacterium bifidum probiotics and the lowest viability was observed when yogurt was stored at $6^{\circ} \mathrm{C}$.

Keywords: Probiotics; Set yogurt; Shelf life; Storage temperature; Viability

Introduction

Yogurt is a product obtained by coagulation of milk with lactic acid fermentation in the presence of microbes such as Streptococcus thermophilus and Lactobacillus bulgaricus [1]. These bacterial species bear symbiotic interactions while growing in milk and develop unique characteristics [2]. To acquire an excellent efficiency for lactic acid production while fermentation, a unique combination of Lactic acid Bacteria (LAB) species is required. However, certain species of LAB that are indigenous to human gastrointestinal tract (GIT) are being used that could survive the high acidity and low $\mathrm{pH}$ of gastrointestinal tract (GIT). These cultures must also be viable in the finished product till its claimed shelf life. The final product must contain more than or equal to $10^{8}$ organisms/gram to meet the criteria as established by National Yogurt Association [2]. The consumer is becoming more diet and health conscious, so the use of probiotic products is also increasing day by day [3]. 
Yogurt is known quite well because of its therapeutic properties [4]. Yogurt is inoculated worldwide with probiotics like Lactobacillus acidophilus. Probiotic yogurt consumption has been found efficient to cure many health issues like diarrhea, enhancing lactose intolerance, urinary and genital tract infections, enhanced cholesterol levels in serum, limiting allergens, promoting anti-carcinogenic activity and enhancing resistance towards diseases [5]. Furthermore, probiotics of yogurt have also been found to have anti-oxidative properties and boost the immune system [6]. Along with the beneficial health properties, yogurt and its probiotics must be economical, should not alter the taste and aroma of yogurt adversely, the shelf life of product must not be affected during its acidification [7]. Storage temperature is a major issue which critically effects yogurt activity; in order to get desirable benefits from probiotic yogurt there should be use of sufficient level of probiotics and adequate storage temperature conditions. Therefore, present study was designed to identify the best storage temperature and adequate level of probiotics use for best yogurt production. By setting the refrigerated temperature there will be maximum growth of beneficial bacteria and hence better results will be obtained.

\section{Materials and Methods}

\section{Procurement of samples}

Buffalo milk procured from B-block UVAS Ravi campus Pattoki, while probiotic cultures procured from local market, Lahore.

\section{Materials}

Lactobacillus MRS Agar, Bifidobacterium Selective Media, M17, Anaerobic Jar, Anaerobic Sachet were also obtained from market.

\section{Standardization of milk}

Buffalo milk yoghurt with different combinations of cultures was prepared. Milk first standardized up to $15 \%$ total solids and
$3.5 \%$ fat. For standardization of yoghurt skim milk powder was added and pasteurized at $82^{\circ} \mathrm{C}$, for 5 minutes, then cooled down to $43^{\circ} \mathrm{C}$, starter culture was added according to the treatments plan. All yogurt batches were incubated at $43^{\circ} \mathrm{C}$ for 3 -3.5 hours. Throughout this period $\mathrm{pH}$ was monitored and at $4.6 \mathrm{pH}$, the batches were shifted to the blast chilling room at $1-2^{\circ} \mathrm{C}$; and then stored at 4,5 and $6^{\circ} \mathrm{C}$ [8].

\section{Starter culture}

Pure DVS culture, Lactobacillus acidophilus and Bifidobacterium bifidum (Chr-Hanson) were procured from local market, Lahore and used in the experiment for yogurt manufacturing. Cultures were prepared and maintained according to the instructions given by the manufacturer.

\section{Culture media for enumeration}

MRS bile agar, M17, (anaerobic sachet) gas packed media were used for enumeration of bacteria. Samples of yogurt were taken and plates were prepared using their respective media and after that these plates were incubated at $37^{\circ} \mathrm{C}$ for the period of $1-3$ days according to the instructions by the manufacturer. For L. acidophilus these plates were incubated aerobically while for B. bifidum plates were incubated anaerobically in gas packed environment. After standardization and pasteurization of milk the cultures were mixed in 1 litter of milk separately. After that above cultured mixed milk was taken and used for further culturing of yogurt according to the method described above and incubated at $42^{\circ} \mathrm{C}$ for 3-3.5 hours at $\mathrm{pH}$ of 4.6 after pasteurization. A total of 4 treatments were prepared in which $1^{\text {st }}$ treatment contained DVS $100 \%$ $\left(\mathrm{B}_{0}\right), 2^{\text {nd }}$ contained $50 \%$ DVS and $50 \%$ Lactobacillus acidophilus (B1), $\quad 3^{\text {rd }}$ contained $50 \%$ DVS and $50 \%$ Bifidobacterium bifidum (B2) and $4^{\text {th }}$ contained 50\% DVS, 25\% Lactobacillus acidophilus and 25\% Bifidobacterium bifidum (B3). All samples were placed at 4, 
5 and $6^{\circ} \mathrm{C}$ to check viability of bacteria for 28 days.

\section{Statistical analysis}

Quality comparison of all prepared yoghurt samples was statistically analyzed by use of Three-way Analysis of Variance (ANOVA) under Completely Randomized Design (CRD). Duncan's Multiple Range (DMR) Test (SAS 9.4 Statistical Software) was used for significant difference comparisons [9].

\section{Results}

Yogurt is most popular food in the world due to its wonderful health benefits for humans. It contained several important microorganisms that are very helpful for human gut and immunity. These probiotics give strong immune system and provides several beneficial effects for cardiac patients. Viability of probiotics is important consideration in order to get desired health benefits. In present study, yogurt was prepared using different cultures such as control group (DVS 100\%) represents Bo, Bifidobacterium bifidum 50\% with DVS $50 \%$ represents to B1, Lactobacillus acidophilus 50\% with DVS 50\% represents B2 and Bifidobacterium bifidum $25 \%+$ Lactobacillus acidophilus $25 \%$ with DVS $50 \%$ represents B3. Also 3 different temperatures were used to study the shelf life and chemical nature of yogurt that were 4, 5 and $6^{\circ} \mathrm{C}$ (T1, T2 and T3) respectively. The effect of variation in the physicochemical nature of yogurt was also studied across four weeks. The CFU count/ viability was also studied using different cultures in yogurt.

\section{Yogurt cultures (Treatments)}

Lactobacillus acidophilus was more stable than Bifidobacterium bifidum and yogurt culture bacteria. Lactobacillus acidophilus showed greater viability, low viability loss percentage than other probiotics because it can survive at low $\mathrm{pH}$, low acidity as compared to Bifidobacterium bifidum and yogurt culture bacteria. The $\mathrm{pH}$ value in $\mathrm{B} 2$ is high which means good stability of Lactobacillus acidophilus than B1, B3 and B0 respectively (Table 1).

Similarly in terms of acidity\% treatment B2 showed low acidity as compared to other three treatments (Table 2). Our results are in agreement with [10], in their study they revealed that Bifidobacterium bifidum is less acid tolerant and less viable at low $\mathrm{pH}$. They concluded that Lactobacillus acidophilus can survive up to $4.0 \mathrm{pH}$ but Bifidobacterium bifidum cannot survive below $5 \mathrm{pH}$. So at low $\mathrm{pH}$ and high acidity Lactobacillus acidophilus showed maximum viability than other probiotics [10]. Our results also showed same trend (Fig 2).

Yogurt containing Lactobacillus acidophilus showed less increase in the syneresis as compared to others as shown in (Table 3). The reason behind the low syneresis value of Lactobacillus acidophilus was its acid tolerance ability which is high as compared to other microorganisms. Lactobacillus acidophilus survives at low $\mathrm{pH}$ and high acidity, so it had less syneresis. Bifidobacterium bifidum showed less syneresis value and it was high for control (B0) [11]. Due to high tolerance of Lactobacillus acidophilus the production of lactic acid was less, this might be due to exopolysaccharides [12].

The Syneresis of yogurt of all treatments increased with the increase in storage time from day 0 to day 28 . For first week it was lower because of low activity of lactic acid bacteria and low $\mathrm{CO}_{2}$ production. But at day 28 it was maximum (Fig. 3) as lactic acid production was high and $\mathrm{pH}$ was low. [11] in their study also revealed that increase in syneresis directly related to increase in acidity and decrease in $\mathrm{pH}$. They showed that syneresis value for first 2 weeks increased slowly but at the end of $4^{\text {th }}$ week it was high, as acidity was high. 
Table 1. Effect of storage temperature and storage period on $\mathrm{pH}$ of yogurt

\begin{tabular}{|c|c|c|c|c|c|}
\hline \multirow{2}{*}{ Temperature } & \multirow{2}{*}{ Storage ( Days) } & \multicolumn{4}{|c|}{ Treatments } \\
\hline & & Bo & B1 & B2 & B3 \\
\hline \multirow[t]{5}{*}{ T1 } & 0 & $4.5667^{\mathrm{a}}$ & $4.5833^{\mathrm{a}}$ & $4.5833^{\mathrm{a}}$ & $4.5867^{\mathrm{a}}$ \\
\hline & 7 & $4.5433^{\mathrm{a}}$ & $4.4600^{\mathrm{b}}$ & $4.4700^{\mathrm{b}}$ & $4.4800^{\mathrm{b}}$ \\
\hline & 14 & $4.4700^{\mathrm{b}}$ & $4.3300^{c}$ & $4.3200^{\mathrm{d}}$ & $4.3567^{\mathrm{e}}$ \\
\hline & 21 & $4.1733^{\mathrm{d}}$ & $4.2200 \mathrm{c}^{\mathrm{d}}$ & $4.2133 \mathrm{~d}^{\mathrm{e}}$ & $4.1867 \mathrm{e}^{\mathrm{f}}$ \\
\hline & 28 & $4.0333^{\mathrm{f}}$ & $4.0800 \mathrm{e}$ & $4.1033^{\mathrm{e}}$ & $4.0700^{\mathrm{g}}$ \\
\hline \multirow[t]{5}{*}{ T2 } & 0 & $4.5767^{\mathrm{a}}$ & $4.5700^{\mathrm{a}}$ & $4.5767^{\mathrm{a}}$ & $4.5800^{\mathrm{a}}$ \\
\hline & 7 & $4.5300^{\mathrm{a}}$ & $4.4167^{\mathrm{c}}$ & $4.4400^{c}$ & $4.4500^{\mathrm{c}}$ \\
\hline & 14 & $4.4533^{\mathrm{b}}$ & $4.2633^{\mathrm{c}}$ & $4.3100^{\mathrm{d}}$ & $4.3233^{\mathrm{e}}$ \\
\hline & 21 & $4.2033^{\mathrm{d}}$ & $4.1200 \mathrm{~d}^{\mathrm{e}}$ & $4.1567^{\mathrm{e}}$ & $4.2033^{\mathrm{ef}}$ \\
\hline & 28 & $4.0200^{\mathrm{f}}$ & $4.0667^{\mathrm{e}}$ & $4.0867^{f}$ & $4.0700^{\mathrm{g}}$ \\
\hline \multirow[t]{5}{*}{ T3 } & 0 & $4.5667^{\mathrm{a}}$ & $4.5667^{\mathrm{a}}$ & $4.5833^{\mathrm{a}}$ & $4.5800^{\mathrm{a}}$ \\
\hline & 7 & $4.5000^{\mathrm{b}}$ & $4.4267^{\mathrm{b}}$ & $4.4200^{c}$ & $4.4167^{\mathrm{d}}$ \\
\hline & 14 & $4.2833^{\mathrm{c}}$ & $4.2967^{\mathrm{c}}$ & $4.3000^{\mathrm{d}}$ & $4.2733^{\mathrm{f}}$ \\
\hline & 21 & $4.0933^{\mathrm{e}}$ & $4.0900^{\mathrm{de}}$ & $4.1067^{\mathrm{ef}}$ & $4.1367^{\mathrm{ef}}$ \\
\hline & 28 & $4.0000^{\mathrm{f}}$ & $4.0433^{\mathrm{d}}$ & $4.0533^{f}$ & $4.0533^{\mathrm{g}}$ \\
\hline
\end{tabular}

Different superscripts indicate significance of a treatment according to the temperature *days interaction

Bo $=$ DVS $100 \%$ (Control)

B1 = Bifidobacterium bifidum 50\% + DVS 50\%

B2 = Lactobacillus acidophilus 50\% + DVS 50\%

B3 = DVS 50\% + Bifidobacterium bifidum 25\% + Lactobacillus acidophilus $25 \%$

Whereas $\mathrm{T} 1=4^{\circ} \mathrm{C}, \mathrm{T} 2=5^{\circ} \mathrm{C}, \mathrm{T} 3=6^{\circ} \mathrm{C}$

$\mathrm{pH}$ was decreased with the increase of temperature and passage of time (Fig. 1)

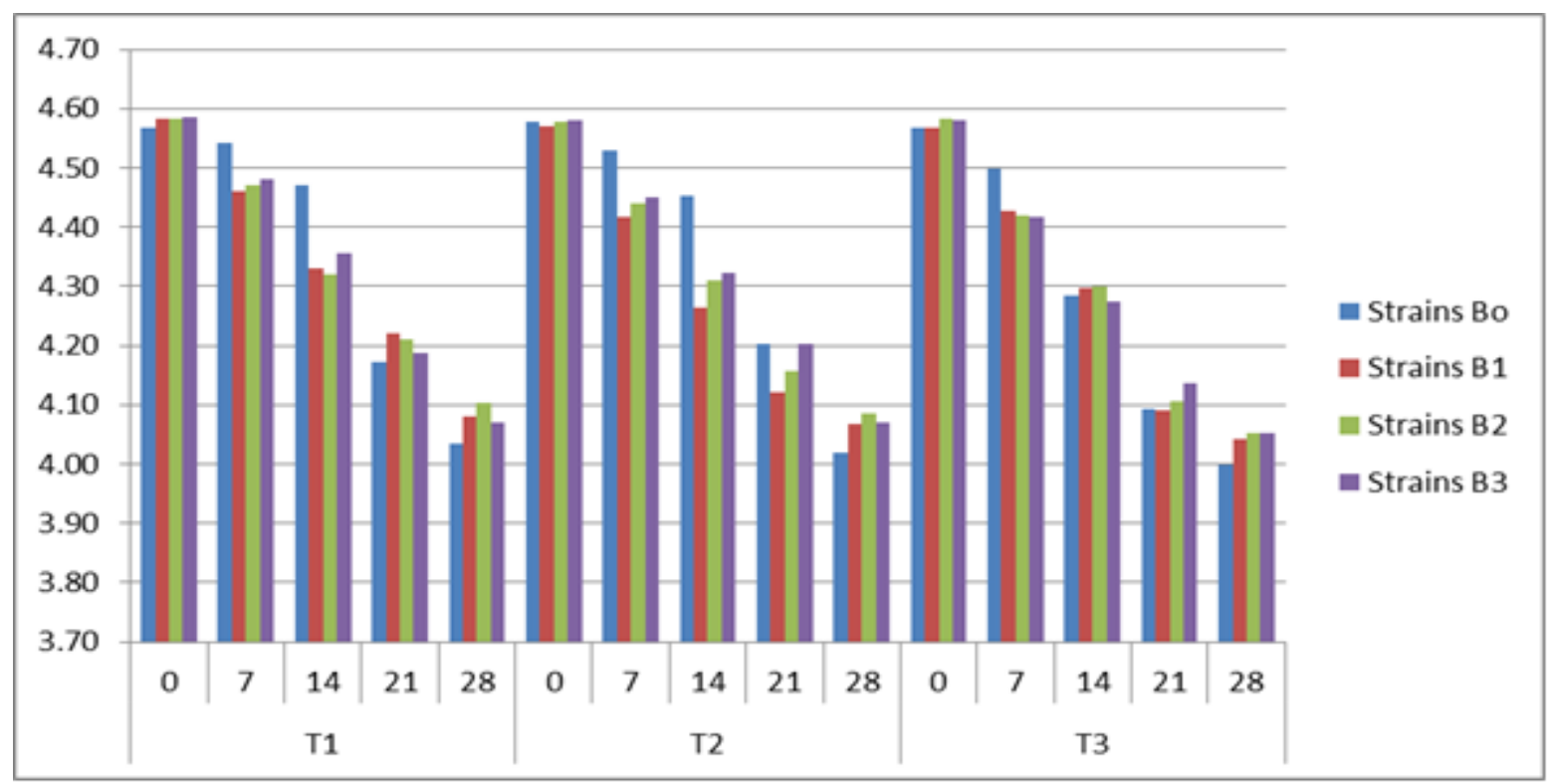

Whereas: $\mathrm{T} 1=4^{\circ} \mathrm{C}, \mathrm{T} 2=5^{\circ} \mathrm{C}, \mathrm{T} 3=6^{\circ} \mathrm{C}$

Figure 1. Results showed that storage temperature and storage days had significant effect (P-value $<\mathbf{0 . 0 5}$ ) on pH of yogurt 
Table 2. Effect of storage temperature and storage period on Acidity\% of yogurt

\begin{tabular}{|c|c|c|c|c|c|}
\hline Temperature & Storage & \multicolumn{4}{|c|}{ Treatments } \\
\hline & & Bo & B1 & B2 & B3 \\
\hline T1 & 0 & $0.9100^{\mathrm{c}}$ & $0.9133^{\mathrm{c}}$ & $0.9087^{\mathrm{f}}$ & $0.9033^{\mathrm{f}}$ \\
\hline & 7 & $0.9133^{\mathrm{c}}$ & $0.9117^{\mathrm{c}}$ & $0.9127^{\mathrm{f}}$ & $0.9113^{\text {ef }}$ \\
\hline & 14 & $0.9233^{\mathrm{c}}$ & $0.9167^{\mathrm{d}}$ & $0.9117^{\mathrm{f}}$ & $0.9161^{\text {ef }}$ \\
\hline & 21 & $0.9233^{\mathrm{c}}$ & $0.9237^{\mathrm{de}}$ & $0.9447^{\mathrm{d}}$ & $0.9227^{\mathrm{e}}$ \\
\hline & 28 & $0.9267^{\mathrm{c}}$ & $0.9627^{\mathrm{e}}$ & $0.9233^{\mathrm{f}}$ & $0.9287^{\mathrm{e}}$ \\
\hline & 0 & $0.9233^{\mathrm{c}}$ & $0.9333^{\mathrm{b}}$ & $0.9307^{\mathrm{e}}$ & $0.9320^{\mathrm{cd}}$ \\
\hline & 7 & $0.9333^{\mathrm{c}}$ & $0.9433^{\mathrm{b}}$ & $0.9417^{\mathrm{d}}$ & $0.9370^{\mathrm{d}}$ \\
\hline & 14 & $0.9433^{\mathrm{c}}$ & $0.9533^{\mathrm{bc}}$ & $0.9317^{\mathrm{e}}$ & $0.9393^{\mathrm{d}}$ \\
\hline & 21 & $0.9533^{\mathrm{bc}}$ & $0.9553^{\mathrm{bc}}$ & $0.9380^{\mathrm{e}}$ & $0.9433^{\mathrm{c}}$ \\
\hline & 28 & $0.9633^{\mathrm{bc}}$ & $0.958^{7 \mathrm{c}}$ & $0.953^{0 \mathrm{~d}}$ & $0.9533^{\mathrm{c}}$ \\
\hline & 0 & $0.9733^{\mathrm{ab}}$ & $0.9633^{\mathrm{ab}}$ & $0.9633^{\mathrm{bc}}$ & $0.9633^{\mathrm{ab}}$ \\
\hline & 7 & $0.9833^{\mathrm{b}}$ & $0.9733^{\mathrm{b}}$ & $0.9733^{\mathrm{c}}$ & $0.9760^{\mathrm{ab}}$ \\
\hline & 14 & $0.9933^{\mathrm{b}}$ & $0.9817^{\mathrm{b}}$ & $0.9833^{\mathrm{b}}$ & $0.9900^{\mathrm{b}}$ \\
\hline & 21 & $1.0167^{\mathrm{b}}$ & $0.9917^{\mathrm{b}}$ & $0.9920^{\mathrm{a}}$ & $0.9953^{\mathrm{a}}$ \\
\hline & 28 & $1.0933^{\mathrm{a}}$ & $0.9967^{\mathrm{a}}$ & $0.9950^{\mathrm{a}}$ & $0.9983^{\mathrm{a}}$ \\
\hline
\end{tabular}

Different superscripts indicate significance of a treatment according to temperature *days interaction

Bo $=$ DVS $100 \%$ (Control)

B1 = Bifidobacterium bifidum 50\% + DVS 50\%

B2 = Lactobacillus acidophilus 50\% + DVS 50\%

B3 = DVS 50\% + Bifidobacterium bifidum 25\% + Lactobacillus acidophilus $25 \%$

Whereas $\mathrm{T} 1=4^{\circ} \mathrm{C}, \mathrm{T} 2=5^{\circ} \mathrm{C}, \mathrm{T} 3=6^{\circ} \mathrm{C}$

Acidity\% increased with the increase of temperature and passage of time (Fig 2).

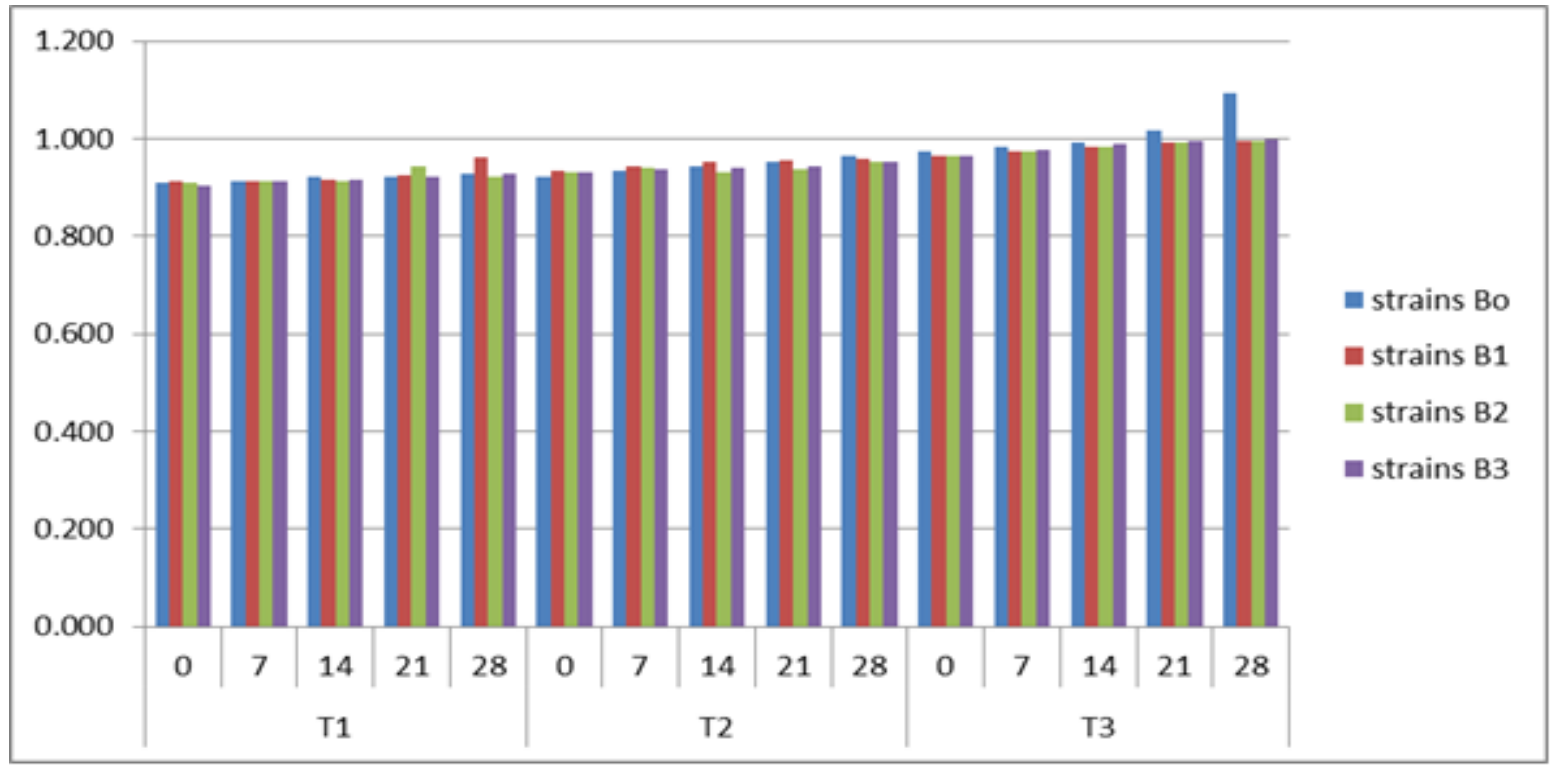

Whereas: $\mathrm{T} 1=4^{\circ} \mathrm{C}, \mathrm{T} 2=5^{\circ} \mathrm{C}, \mathrm{T} 3=6^{\circ} \mathrm{C}$

Figure 2. Results showed that storage temperature and storage days had significant effect (P-value <0.05) on Acidity\% of yogurt 
Table 3. Effect of storage temperature and storage period on syneresis (\%) of yogurt

\begin{tabular}{|c|c|c|c|c|c|}
\hline \multirow[t]{2}{*}{ Temperature } & \multirow[t]{2}{*}{ Storage } & \multicolumn{4}{|c|}{ Treatments } \\
\hline & & Вo & B1 & B2 & B3 \\
\hline \multirow[t]{5}{*}{ T1 } & 0 & $49.0333^{\mathrm{g}}$ & $48.6333^{\mathrm{g}}$ & $48.2333^{\mathrm{g}}$ & $48.3333^{\mathrm{g}}$ \\
\hline & 7 & $49.2667^{\mathrm{g}}$ & $48.9067^{\mathrm{fg}}$ & $48.4333^{f}$ & $48.4333 \mathrm{f}^{\mathrm{g}}$ \\
\hline & 14 & $49.6333^{\mathrm{fg}}$ & $48.9467^{\mathrm{fg}}$ & $48.5333^{\text {ef }}$ & $48.5000^{f}$ \\
\hline & 21 & $49.8333^{\mathrm{f}}$ & $49.0667^{\mathrm{f}}$ & $48.6333^{f}$ & $48.6333^{f}$ \\
\hline & 28 & $50.0333^{\text {ef }}$ & $49.2333^{\mathrm{ef}}$ & $48.9333^{\mathrm{ef}}$ & $48.8333^{\mathrm{ef}}$ \\
\hline \multirow[t]{5}{*}{$\mathbf{T 2}$} & 0 & $50.3333^{\mathrm{e}}$ & $49.3333^{\mathrm{e}}$ & $49.0333^{\mathrm{e}}$ & $49.0333^{\mathrm{e}}$ \\
\hline & 7 & $50.5333^{\mathrm{de}}$ & $49.4333^{\mathrm{e}}$ & $49.1333^{\mathrm{e}}$ & $49.3333^{\mathrm{de}}$ \\
\hline & 14 & $50.6333^{\mathrm{de}}$ & $49.6333^{\mathrm{de}}$ & $49.3333^{\mathrm{d}}$ & $49.5333^{d}$ \\
\hline & 21 & $50.8333^{d}$ & $49.8333^{\mathrm{de}}$ & $49.4667^{\mathrm{cd}}$ & $49.7333^{\mathrm{d}}$ \\
\hline & 28 & $50.9333^{d}$ & $49.9333^{\mathrm{de}}$ & $49.6333^{c d}$ & $49.9333^{\mathrm{cd}}$ \\
\hline \multirow[t]{5}{*}{ T3 } & 0 & $51.0333^{\mathrm{cd}}$ & $50.0333^{\mathrm{d}}$ & $49.9333^{c}$ & $50.0333^{c}$ \\
\hline & 7 & $51.2333^{c}$ & $50.2333^{\mathrm{cd}}$ & $50.0333^{\mathrm{bc}}$ & $50.3333^{\mathrm{ab}}$ \\
\hline & 14 & $51.3333^{b}$ & $50.4333^{c}$ & $50.1333^{\mathrm{ab}}$ & $50.4333^{b}$ \\
\hline & 21 & $51.5333^{\mathrm{a}}$ & $50.7333^{b}$ & $50.2333^{b}$ & $50.5667^{b}$ \\
\hline & 28 & $51.6333^{\mathrm{a}}$ & $50.9333^{\mathrm{a}}$ & $50.3333^{a}$ & $50.7333^{a}$ \\
\hline \multicolumn{2}{|c|}{ P-Value } & \multicolumn{4}{|c|}{$<0.01$} \\
\hline
\end{tabular}

Different superscripts indicate significance of a treatment according to temperature *days interaction

Bo $=$ DVS $100 \%$ (Control)

B1 = Bifidobacterium bifidum 50\% + DVS 50\%

B2 $=$ Lactobacillus acidophilus $50 \%+$ DVS $50 \%$

B3 = DVS 50\% + Bifidobacterium bifidum 25\% + Lactobacillus acidophilus $25 \%$

Whereas $\mathrm{T} 1=4^{\circ} \mathrm{C}, \mathrm{T} 2=5^{\circ} \mathrm{C}, \mathrm{T} 3=6^{\circ} \mathrm{C}$

Syneresis increased with the increase of temperature and passage of time (Fig 3).

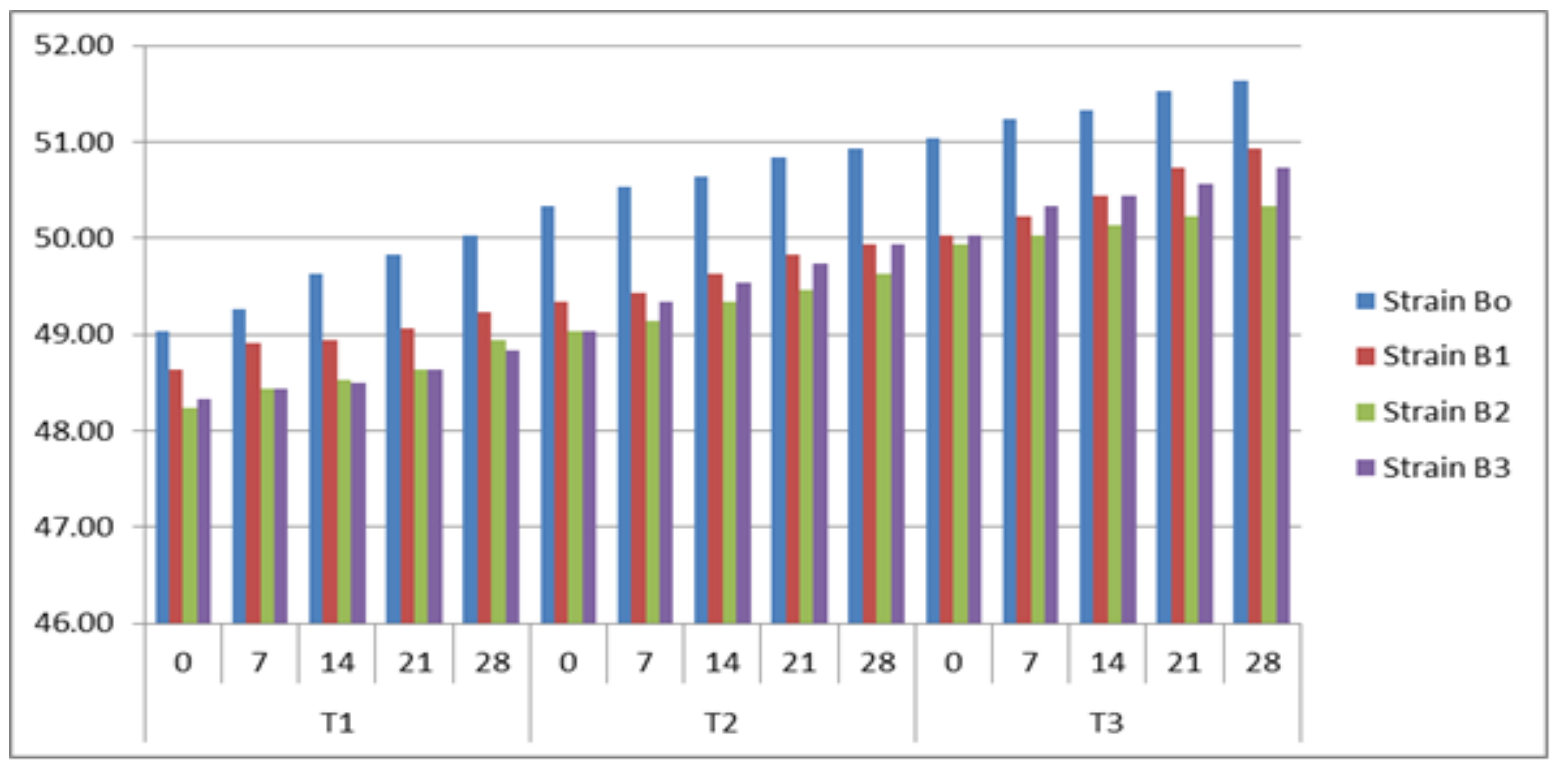

Whereas: $\mathrm{T} 1=4^{\circ} \mathrm{C}, \mathrm{T} 2=5^{\circ} \mathrm{C}, \mathrm{T} 3=6^{\circ} \mathrm{C}$

Figure 3. Results showed that storage temperature and storage days had significant effect (P-value $<0.05$ ) on Syneresis of yogurt. 
The CFU/ viability in case of B2 was high than B3, B1 and B0. Lactobacillus acidophilus showed more viability than other three treatments because of synergistic relationship of Lactobacillus acidophilus with yogurt bacteria (Table 4) and (Fig 4). Yogurt bacteria made synergism with the probiotics hence there was less lactic acid production and less acidity, so viability loss percentage was low. On the other hand Bifidobacterium being less acid tolerant and less survived at low $\mathrm{pH}$ even below $\mathrm{pH} 5$ had high viability loss percentage as compared to Lactobacillus acidophilus [13].

\section{Temperature}

By maintaining proper temperature which is necessary for optimum growth of probiotics in yogurt, the therapeutic as well as economic benefits of yogurt will be achieved. Hence present study was designed and the results indicated that the $\mathrm{CFU}$ values of temperatures (T1-T3) varied significantly. The results of CFU of yogurt made from buffalo milk are demonstrated in (Fig 4). Maximum CFU was observed for T1 while minimum CFU was observed for T3. Reason for survival at low temperature is that, at low temperature the production of lactic acid by Lactobacillus bulgaricus is low so both Lactobacillus acidophilus and Bifidobacterium bifidum showed greatest viability at low temperature like $4^{\circ} \mathrm{C}$. In the same case Lactobacillus acidophilus and Bifidobacterium bifidum showed low viability at high temperature as mentioned in the study $5^{\circ} \mathrm{C}$ and $6^{\circ} \mathrm{C}$, as on these temperatures the production of lactic acid bacteria high which retarded the growth of these probiotics and ultimately reduced number of viable count [14].

Table 4. Effect of Storage temperature and storage period on Probiotic viability (log cfu/ml) of yogurt

\begin{tabular}{|c|c|c|c|c|c|}
\hline Temperature & Storage & \multicolumn{5}{|c|}{ Treatments } \\
\hline & & Bo & B1 & B2 & B3 \\
\hline T1 & 0 & $7.1683^{\mathrm{a}}$ & $7.3433^{\mathrm{a}}$ & $7.4633^{\mathrm{a}}$ & $7.3167^{\mathrm{a}}$ \\
\hline & 7 & $7.1200^{\mathrm{b}}$ & $7.2067^{\mathrm{b}}$ & $7.4133^{\mathrm{b}}$ & $7.2300^{\mathrm{b}}$ \\
\hline & 14 & $6.7867^{\mathrm{c}}$ & $6.9333^{\mathrm{c}}$ & $6.7933^{\mathrm{c}}$ & $6.7983^{\mathrm{c}}$ \\
\hline & 21 & $6.5083^{\mathrm{d}}$ & $6.5333^{\mathrm{d}}$ & $6.7000^{\mathrm{d}}$ & $6.5317^{\mathrm{d}}$ \\
\hline & 28 & $6.1750^{\mathrm{de}}$ & $6.2333^{\mathrm{de}}$ & $5.5733^{\mathrm{e}}$ & $5.8550^{\mathrm{e}}$ \\
\hline & 0 & $7.1683^{\mathrm{a}}$ & $7.3433^{\mathrm{a}}$ & $7.4633^{\mathrm{a}}$ & $7.3183^{\mathrm{a}}$ \\
\hline & 7 & $7.0450^{\mathrm{ab}}$ & $7.0667^{\mathrm{b}}$ & $7.4133^{\mathrm{b}}$ & $7.1950^{\mathrm{b}}$ \\
\hline & 14 & $6.7733^{\mathrm{c}}$ & $6.8333^{\mathrm{c}}$ & $6.7333^{\mathrm{c}}$ & $6.7917^{\mathrm{c}}$ \\
\hline & 21 & $6.2400 \mathrm{~d}^{\mathrm{e}}$ & $6.2133^{\mathrm{de}}$ & $6.2333^{\mathrm{de}}$ & $6.2067^{\mathrm{de}}$ \\
\hline & 28 & $5.3717^{\mathrm{e}}$ & $5.4667^{\mathrm{e}}$ & $5.6333^{\mathrm{e}}$ & $5.5217^{\mathrm{e}}$ \\
\hline & 0 & $7.1733^{\mathrm{a}}$ & $7.3433^{\mathrm{a}}$ & $7.4667^{\mathrm{a}}$ & $7.3333^{\mathrm{a}}$ \\
\hline & 7 & $7.0150^{\mathrm{b}}$ & $7.0833^{\mathrm{ab}}$ & $7.4267^{\mathrm{b}}$ & $7.2383^{\mathrm{b}}$ \\
\hline & 14 & $6.6783^{\mathrm{c}}$ & $6.7333^{\mathrm{cd}}$ & $6.6333^{\mathrm{d}}$ & $6.6783^{\mathrm{cd}}$ \\
\hline & 21 & $6.0333^{\mathrm{de}}$ & $6.1667^{\mathrm{de}}$ & $6.4167^{\mathrm{de}}$ & $6.2750^{\mathrm{de}}$ \\
\hline & 28 & $5.3433^{\mathrm{e}}$ & $5.3333^{\mathrm{e}}$ & $6.0333^{\mathrm{de}}$ & $5.6567^{\mathrm{e}}$ \\
\hline
\end{tabular}

Different superscripts indicate significance of a treatment according to temperature *days interaction

Bo $=$ DVS $100 \%$ (Control)

B1 = Bifidobacterium bifidum $50 \%+$ DVS $50 \%$

B2 = Lactobacillus acidophilus 50\% + DVS 50\%

B3 = DVS 50\% + Bifidobacterium bifidum 25\% + Lactobacillus acidophilus $25 \%$

Whereas $\mathrm{T} 1=4^{\circ} \mathrm{C}, \mathrm{T} 2=5^{\circ} \mathrm{C}, \mathrm{T} 3=6^{\circ} \mathrm{C}$ 
Viability decreased with the increase of temperature and passage of time (Fig 4).

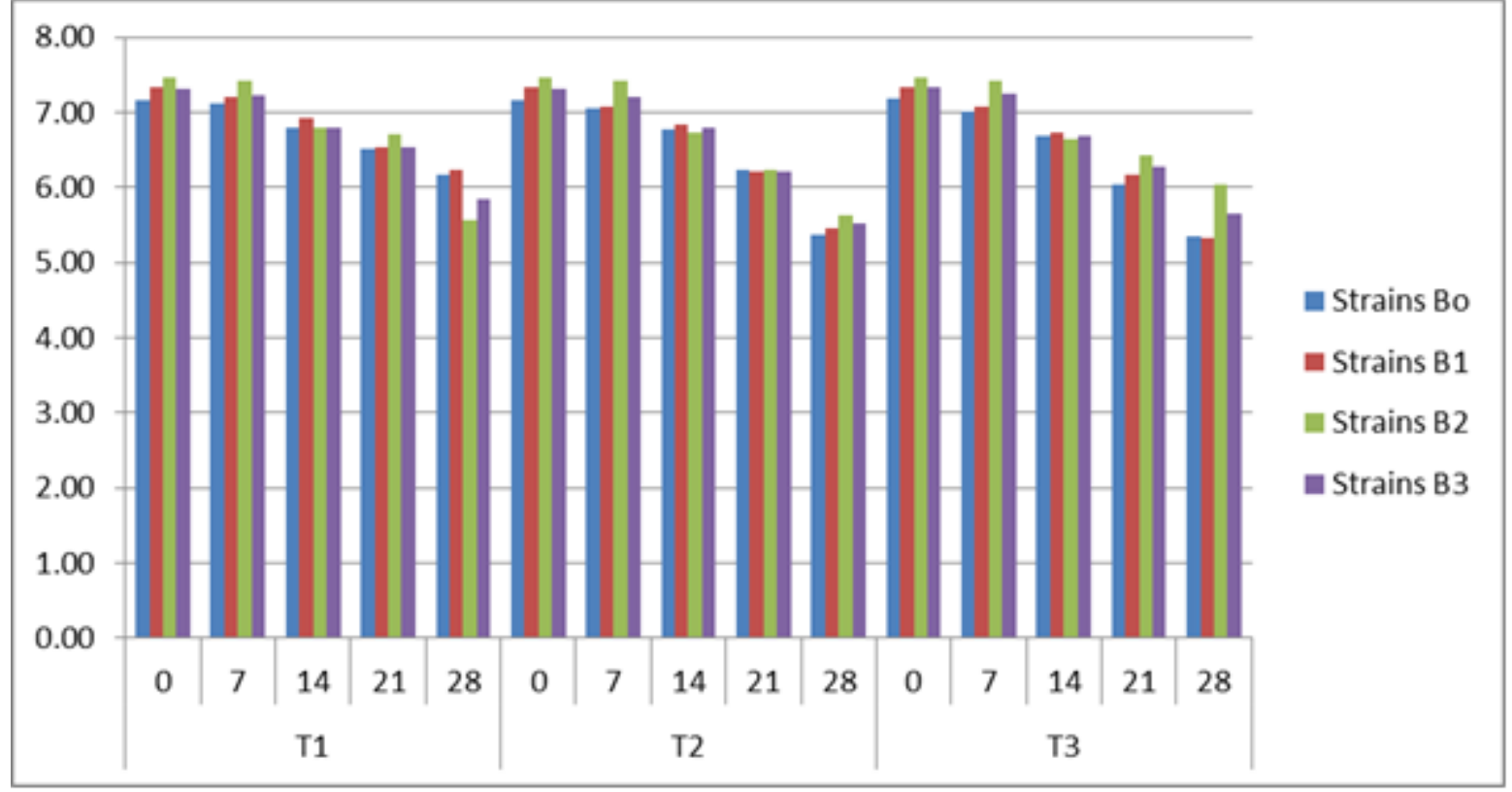

Whereas: $\mathrm{T} 1=4^{\circ} \mathrm{C}, \mathrm{T} 2=5^{\circ} \mathrm{C}, \mathrm{T} 3=6^{\circ} \mathrm{C}$

Figure 4.Results showed that storage temperature and storage days had significant effect $(P$ value $<0.05$ ) on Viability of yogurt.

$\mathrm{pH}$ at $6^{\circ} \mathrm{C}$ was low as compared to $5^{\circ} \mathrm{C}$ and $4^{\circ} \mathrm{C}$ because of high activity of lactic acid bacteria at increased temperature (Fig 1). At $6^{\circ} \mathrm{C}$ there was more lactic acid formation and more viability loss so at that temperature there was low $\mathrm{pH}$ at $6^{\circ} \mathrm{C}$. Lactobacillus acidophilus and Bifidobacterium bifidum showed better survival rate at low storage temperature because of less production of lactic acid in the yogurt and low acidity (Fig 2). At high temperature metabolic activity of cell high and death rate of bacterial cell increased due to this reason at high temperature viability loss increased as compared to low temperature 4 and $5^{\circ} \mathrm{C}[15]$.

The Syneresis of yogurt of all treatments increased (Fig 3) with the increase of temperature. (Fox and Cagan 2017) in their study also revealed that increase in syneresis directly related to increase in acidity and decrease in $\mathrm{pH}$. They also concluded that increase in temperature increased the syneresis as with increase in temperature,
$\mathrm{pH}$ decreased and acidity increased [11]. When temperature increases viscosity decreases because of high metabolic activity of microorganisms and high lactic acid formation [16].

\section{Shelf life}

At first week of storage the viability loss was low as compared to $3^{\text {rd }}$ and $4^{\text {th }}$ week (Fig 4). [13] in study also revealed that there was decrease in viability of probiotics observed across the weeks. They detected that with the increase of storage time the viability of probiotics decreased and its viability percentage loss increased. This was due to increased activity of Lactobacillus bulgaricus and antagonistic relationship of yogurt bacteria with these probiotics [13]. The decrease of $\mathrm{pH}$ and increase in acidity\% of yogurt of all treatments (Lactobacillus acidophilus, Bifidobacterium bifidum and yogurt culture bacteria) occurred as the time passed. Maximum $\mathrm{pH}$ was observed at week 1 and lowest $\mathrm{pH}$ was observed at week 4. So from week1-4 $\mathrm{pH}$ of yogurts decreased. This 
is due to high lactic acid production from lactose by these bacteria. They produced lactic acid, and production was maximum after 4 weeks of storage. The lactose of yogurt was utilized by lactic acid bacteria which converted it to lactic acid and as a result $\mathrm{pH}$ decreased and acidity increased. This occurred might be due to buffering action of proteins [17].

\section{Conclusion and Recommendations}

Probiotics are beneficial for human health, so their viable count should meet the required quantity in order to get good results. Various probiotics are available in the market, present study suggests Lactobacillus acidophilus is best among all these probiotics. Lactobacillus acidophilus gave maximum viable count than yogurt culture and Bifidobacterium bifidum. Maximum viability of probiotics was obtained when these probiotics stored at $4{ }^{\circ} \mathrm{C}$ and afterwards their viability decreased due to increased metabolic activity of the microbes. Viability loss percentage for both strains was maximum when yogurt stored at $6^{\circ} \mathrm{C}$ on day $28^{\text {th }}$. So for probiotic yogurt, optimum conditions for better quality, sensory properties and to enhance shelf life it must be stored at $4^{\circ} \mathrm{C}$. If this strain will use with yogurt bacteria (Streptococcus thermophilus and Lactobacillus bulgaricus) then there will be best therapeutics as well as quality results will be obtained.

\section{Authors' contributions}

Conceived and designed the experiments: $S$ Inayat, Performed the experiments: M Bilal, Analyzed the data: S Manzoor, Contributed reagents/ materials/ analysis tools: $\mathrm{MH}$ Lashari \& A Hassan, Wrote the paper: S Inayat.

\section{Acknowledgements}

This study was carried out at Department of Dairy Technology Laboratories in University of Veterinary and Animal Sciences, Ravi Campus, Pattoki, Pakistan. The authors are grateful to the institute and
Higher Education Commission, Islamabad.

\section{References}

1. Montalto M, Curigliano V, Santoro L, Vastola M, Cammarota G, Manna R, Gasbarrini A \& Gasbarrini G (2006). Management and treatment of lactose malabsorption. World J Gastroenterol 12(2): 187.

2. Hui YH (1993). Dairy science and Technology Handbook. VCH. The University of Wisconsin- Madison. USA.

3. Tripathi MK \& Giri SK (2014). Probiotic functional foods: Survival of probiotics during Processing and storage. J Funct Foods. 9: 225-241.

4. Giraffa G (2012). Selection and design of lactic acid bacteria. Eng Life Sci 12(4): 391-398.

5. Hotel ACP \& Cordoba A (2001). Health and nutritional properties of probiotics in food including powder milk with live lactic acid bacteria. Prevention 5(1):110.

6. Mishra V, Shah C, Mokashe N, Chavan R, Yadav H \& Prajapati J (2015). Probiotics as Potential antioxidants: a systematic review. J Agric Food Chem 63(14): 3615-3626.

7. Heller KJ (2001). Probiotic bacteria in fermented foods: product characteristics and starter organisms. Am J Clin Nutr 73(2): 374-379.

8. Tamime AY \& Robinson RK (2007). Tamime and Robinson's yoghurt: science and Technology. Elsevier.

9. Infante E, Buono D \& Buono A (2015). A 3-way anova a priori test for common seasonal patterns and its application to direct versus indirect methods. Eurostat Review on National Accounts and Macroeconomic Indicators, pp. 67-77.

10. Shah N \& Jelen P (1990). Survival of lactic acid bacteria and their lactases under acidic conditions. J Food Sci 55(2): 506-509. 
11. Fox PF, Guinee TP, Cogan TM \& McSweeney PL (2017). Fundamentals of cheese science. Springer.

12. Donkor ON, Nilmini SLI, Stolic P, Vasiljevic T \& Shah NP (2007). Survival and activity of selected probiotic organisms in set-type yoghurt during cold storage. Int Dairy J 17(6): 657-665.

13. Mortazavian A, Ehsani M, Mousavi S, Rezaei K, Sohrabvandi S \& Reinheimer J (2007). Effect of refrigerated storage temperature on the viability of probiotic microorganisms in yogurt. Int J Dairy Tech 60(2): 123-127.

14. Mortazavian A, Ehsani M, Mousavi S, Sohrabvandi S \& Reinheimer J (2006). Combined effects of temperature- related variables on the viability of probiotic micro-organisms in yogurt. Aust J Dairy Techno 61(3): 248.

15. Laroia S \& Martin J (1991). Methods for enumerating and propagating bifidobacteria. pp 32-33.

16. 16 Beal C, Skokanova J, Latrille E, Martin N \& Corrieu G (1999). Combined effects of culture conditions and storage time on acidification and viscosity of stirred yogurt. J Dairy Sci 82(4): 673-681.

17. Shah NP, Lankaputhra WE, Britz ML \& Kyle WS (1995). Survival of Lactobacillus acidophilus and Bifidobacterium bifidum in commercial yoghurt during refrigerated storage. Int Dairy J 5(5): 515-521. 